\title{
Influence of paclobutrazol and cycocel sprays on the growth, flowering and chemical composition of potted Chrysanthemum frutescens plant
}

\author{
Ghatas, Y.A.A. \\ Horticulture, Dept. Fac. of Agric., Benha University, Egypt. \\ Corresponding Author: yasser.abdelaty@fagr.bu.edu.eg
}

\begin{abstract}
A pot experimental study was carried out during the two successive seasons of 2013 and 2014 to study the effect of paclobutrazol at 0.0, 20,40 and $60 \mathrm{ppm}$ and cycocel at 0.0, 1000, 2000 and $3000 \mathrm{ppm}$ on growth, flowering and chemical composition of potted Chrysanthemum frutescens plant. Uniform terminal cuttings were planted in $8 \mathrm{~cm}$ plastic pots containing 1:1 mixture of peat moss and sand. On March $1^{\text {st }} 2013$ and 2014 , uniform well rooted cuttings were repotted in $20 \mathrm{~cm}$ diameter plastic pots filled with a mixture of 1 clay: 1 sand $: 1$ peat moss (v:v:v). After one month from the repotting process, plants received four sprays of paclobutrazol at 20, 40 and $60 \mathrm{ppm}$ and cycocel at 1000, 2000 and 3000 ppm plus tap water as control at two weeks intervals. The obtained results cleared that all paclobutrazol and cycocel concentrations decreased plant height, particularly paclobutrazol at $60 \mathrm{ppm}$ in both seasons. Meanwhile, all applied treatments of paclobutrazol and cycocel statistically increased branches number / plant to reach its maximum with the highest concentration for each. The heaviest fresh and dry weights of leaves/plant were gained by $3000 \mathrm{ppm}$ cycocel-sprayed plants in the two seasons. Also, paclobutrazol and cycocel treatments delayed the flowering of Chrysanthemum frutescens plant when compared with control plants which induced the earliest flowering in both seasons. The highest number of flowers/ plant was scored by $60 \mathrm{ppm}$ paclobutrazol -sprayed plants. Whereas, the heaviest flowers fresh and dry weights/plant were scored by $3000 \mathrm{ppm}$ cycocel-sprayed plants in the two seasons. Moreover, the highest show value (plant width/ height ratio) was recorded with paclobutrazol and cycocel at the highest concentration in the two seasons. The highest number of roots/plant was scored by $60 \mathrm{ppm}$ paclobutrazolsprayed plants, while the heaviest fresh and dry weights were registered by $3000 \mathrm{ppm}$ cycocel-sprayed plants in both seasons. Furthermore, paclobutrazol and cycocel treatments statistically increased leaf NPK, total carbohydrates and total chlorophylls contents, being superior in the highest concentrations as compared with unsprayed plants in the two seasons. All paclobutrazol and cycocel treatments increased leaf total phenols content (mg/ 100g F.W) but they still reduced total indoles (mg/100g F.W) of Chrysanthemum frutescens leaves.
\end{abstract}

Key words: Chrysanthemum frutescens, pot plant, $\mathrm{PP}_{333}, \mathrm{CCC}$, growth, flowering and chemical composition.

\section{Introduction}

Chrysanthemum frutescens (Argyranthemum frutescens L.), is a perennial plant known for its flowers (yellow, pink, pale pink or white similar with meadows daisy). The genus name is derived from the Green "argyros" (silver) and "anthos" (flower). It contains evergreen short subshrubs (herbs with a woody lower base) with daisy-shaped flowers. It is native to the Canary Islands Their native habitat ranges from the seashore, woodland edges and slopes of volcanic mountains. They make bushy shrubby growth that can be left as a shaggy shape or given a topiarised, manicured look. The foliage which is dissected and filigree-like in blue-green adds to the attraction. Plants have a height of $60-90 \mathrm{~cm}$ and a diameter of bush $40-90 \mathrm{~cm}$. It blooms from summer to autumn on well drained and fertile soils, and exposed to sunlight. It can go straight into reasonably well-drained, well-conditioned garden soil in a warm, sunny position. Thereafter, they need less maintenance works. It is can grow in pots filled with soilless compost and weekly feed with liquid fertilizer (Armitage, 2004).
Compactness is often longed for in horticulturalgrown plants because such plants are aesthetically pleasing and have a long salable period after they reach market size. Also, efficient marketing and transportation may require shorter plants. Commercial growers usually achieve compactness in ornamentals by applying chemical growth regulators. These chemicals shorten cell elongation, often by interfering with synthesis of a naturally occurring hormone, gibberellin. Since chlorophyll-containing cells are much denser in treated plants, the leaves appear darker green. The shorter stem lengths between nodes of plants treated with these gibberellin biosynthesis inhibitors also result in stems that are better capable to support leaves and flowers. Several chemicals are presently available to shorten overall plant height (Rademacher, 2000).

Controlling plant size is one of the most important ambitious of ornamental plants production. producers can control plant height genetically, environmentally, culturally or chemically. These techniques can be effective height-suppressing strategies for some plants, but when producers are involved with ornamental plants which comprise 
large varieties of genera, species or cultivars, these techniques may not work identically well for each crop under a common environment. A substitute, effective strategy for controlling plant height is to employ the use of chemical plant growth retardants (Chany, 2005). Application of growth retardants is a common practice for commercial growers to attain attractive compact pot-grown plants.

The term growth retardants is used for all chemicals that retard cell division and cell elongation in shoot tissues and adjust plant height physiologically without formative effects (PGRSA, 2007). One of the most widely used growth retardants is paclobutrazol $\left(\mathrm{pp}_{333}\right)$ [(2RS,3RS) -1-(4chlorophenyl-4,4 -dimethyl-2-(1H-1,2,4 triazol-1- yl) pentan-3-ol] (Davis and Andersen, 1989). Paclobutrazol operates by inhibiting cytochrome P450, which mediates oxidative dimethylation reactions, including those which are necessary for the synthesis of ergosterol and the conversion of kaurene to kaurenoic acid in the gibberellins biosynthetic pathway (Fletcher et al., 2000). From this function, paclobutrazol has long been used to slowed down plant height for potted plant production, especially ornamental plants (Beattie et al., 1990; Fletcher et al., 2000). Paclobutrazol at concentration of $75 \mathrm{ppm}$ reduced plant foliage height but it increased flower number / plant and delaying the production of potted Hibiscus rosa sinensis (Turky, 2015). Cycocel (CCC) (chlormequat; 2-chloroethyltrimethyl ammonium chloride) is a synthetic plant growth retardant used on ornamental plants for bringing about dwarfism in plants and shorter internodes, stronger stems and green leaves. It is also utilized in order to produce compact, sturdy potted and bedding plants, promote the green colour of the foliage, strengthen flower stem and elevate resistance of foliage to environmental stresses. Although growth reduction effect of cycocel is regular, growth reduction percentage, flowering, leaf area and chlorophyll content, flower shape and colour responses of plants to this chemical can differ depending on the dose or concentration, method, site of application, species and cultivar and also growing season (Taiz and Zeiger, 2006). Therefore, the aim of this study was to evaluate the effects of paclobutrazol and cycocel on growth, flowering and chemical composition of potted Chrysanthemum frutescens plants.

\section{Materials and Methods}

This study was carried out during the two successive seasons of 2013 and 2014 at the Experimental lathhouse of Horticulture Dept., Faculty of Agric., Benha University, Kalubia Governorate, Egypt to study the effect of some paclobutrazol and cycocel treatments on growth , flowering and chemical composition of potted Chrysanthemum frutescens plants. Uniform terminal cuttings $10-11 \mathrm{~cm}$ length and $0.27-0.29 \mathrm{~cm}$ in thickness were planted on January 1st 2013 and 2014in $8 \mathrm{~cm}$ plastic pots containing 1:1 mixture of peat moss and sand. Then, they were placed under plastic tunnel conditions at the lathehouse. On March $1^{\text {st }} 2013$ and 2014, uniform well rooted cuttings producing 3-4 branches at $15-16 \mathrm{~cm}$ height were repotted in $20 \mathrm{~cm}$ diameter plastic pots filled with a mixture of 1 clay: 1 sand :1 peat moss (v:v:v). The chemical characteristics of the planting medium are shown in Table 1. Chemical analysis for the planting medium was determined according to Black $\boldsymbol{e t} \boldsymbol{a l}$. (1982).

Table 1. Chemical analysis of the planting medium.

\begin{tabular}{|c|c|c|c|}
\hline$\overline{\text { Parameters }}$ & Unit & & Seasons \\
\hline & & & 2014 \\
\hline $\mathrm{CaCO}$ & $\%$ & 0.89 & 0.92 \\
\hline Organic matter & $\%$ & 1.82 & 1.79 \\
\hline Available nitrogen & $\%$ & 0.82 & 0.89 \\
\hline Available phosphorus & $\%$ & 0.38 & 0.50 \\
\hline Available potassium & $\%$ & 0.64 & 0.69 \\
\hline E.C & $\mathrm{ds} / \mathrm{m}$ & 1.29 & 1.38 \\
\hline$\overline{\mathrm{pH}}$ & 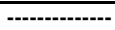 & 6.69 & 6.72 \\
\hline
\end{tabular}

After one month from the repotting process (April $1^{\text {st }}$ during the two seasons), the plants were received four sprays with paclobutrazol at 20,40 and $60 \mathrm{ppm}$ and cycocel at 1000, 2000 and $3000 \mathrm{ppm}$ plus tap water as control at two weeks intervals. The plants were sprayed with a mist hand pump to the point of runoff. A surfactant (Tween 20) at a concentration of $0.01 \%$ was added to all tested solutions including the control. The treatments were arranged at random in three replicates with 15 pots/ each under the lathhouse condition. After one month from replanting, the plants were fertilized every month with a chemical NPK fertilizer using ammonium sulfate $(20.5 \% \quad \mathrm{~N}), \quad$ calcium superphosphate $(15.5 \% \mathrm{P} 2 \mathrm{O} 5)$ and potassium sulfate $\left(48 \% \mathrm{~K}_{2} \mathrm{O}\right)$. A mixture of the three fertilizers, with a ratio of 1: 1: $1\left(\mathrm{~N}: \mathrm{P}_{2} \mathrm{O}_{5}: \mathrm{K}_{2} \mathrm{O}\right)$, was prepared and applied to the pots at the rate of $6 \mathrm{~g} /$ pot. Common agricultural practices (irrigation, manual weed control, etc.) were carried out when needed. 
Recorded data:

I- Growth parameters:

Vegetative and flowering characteristics were taken down at full flowering stage (September $1^{\text {st }}$ during the two seasons) which included plant height (measured from surface of the potting medium to the uppermost branch), number of branches/ plant, fresh and dry weights of leaves/ plant, days from planting to flowering, number of flowers/ plant, fresh and dry weights of flowers/plant and show value (as plant width / plant height ratio according to Berghage et al., (1989)). Whereas, roots measurements were taken at the end of experiment (December $1^{\text {st }}$ during the two seasons) which included roots number/ plant, in addition to fresh and dry weights of roots/plant.

\section{II- Chemical composition determinations:}

Leaves used for chemical analysis were taken just before flowering, dried at $70 \mathrm{C}$ for 72 hours and used for determination of total nitrogen percentage according to A.O.A.C (1990), total phosphorus percentage was determined according to Hucker and Catroux (1980), potassium percentage was determined according to Brown and Lilleland (1946), total carbohydrates percentage was determined according to Herbert et al. (1971). As for total chlorophylls, total indoles and total phenols, they were determined in fresh leaves according to

\section{A.O.A.C (1990).}

\section{Statistical analysis:}

Obtained data of results during the two seasons were subjected to analysis of variance as a simple experiment in a complete randomized block design. LSD method was used to differentiate between means according to Snedecor and Cochran (1989).

\section{Results and Discussion}

\section{A. Effect on the vegetative growth parameters.}

\section{Plant height $(\mathrm{cm})$ :}

Data in Table (2) indicate that all tested concentrations of paclobutrazol and cycocel decreased plant height of Chrysanthemum frutescence plant as compared with un-treated control in both seasons. In all cases, it was observed that there was a negative correlation between the values of plant height and the concentration of paclobutrazol or cycocel. As the concentration of paclobutrazol or cycocel increased the values of plant height decreased until they reached to a maximum drop at the high concentration in the two seasons. In detail, $60 \mathrm{ppm}$ paclobutrazol-sprayed plants produced the lowest values in this regard as it scored 31.2 and $30.6 \mathrm{~cm}$, followed in ascending order by 3000 ppm cycocel-sprayed plants which registered 34.2 and $32.7 \mathrm{~cm}$, in the first and second seasons, respectively. In addition, paclobutrazol and cycocel at the medium concentration recorded highly reduction in plant height values of Chrysanthemum frutescens plants in both seasons.

\section{Branches number/plant:}

Data shown in Table (2) point out that all studied concentrations of paclobutrazol and cycocel increased the number of branches / plant as compared with control plants in both seasons. In all, the highest number of branches/plant was scored by $60 \mathrm{ppm}$ paclobutrazol-sprayed plants as it scored 18.9 and 24.3 branches/plant, followed in descending order by using cycocel at the high concentration $(3000 \mathrm{ppm})$ as it recorded 17.6 and 22.6 branches/plant in the first and second seasons, respectively. Moreover, paclobutrazol at $40 \mathrm{ppm}$ and cycocel at 2000 ppm gave highly significant increases in the number of branches/plant in both seasons.

Table 2. Effect of paclobutrazol and cycocel on plant height and number of branches/plant of Chrysanthemum frutescens during 2013 and 2014 seasons.

\begin{tabular}{|c|c|c|c|c|c|}
\hline \multirow[b]{2}{*}{ Treatments } & \multirow{2}{*}{ Parameters } & \multicolumn{2}{|c|}{ Plant height $(\mathrm{cm})$} & \multicolumn{2}{|c|}{ Branches number/plant } \\
\hline & & $1^{\text {st }}$ Season & $2^{\text {nd }}$ Season & $1^{\text {st }}$ Season & $2^{\text {nd }}$ Season \\
\hline Control & & 47.6 & 49.2 & 13.6 & 15.1 \\
\hline \multirow{3}{*}{ Paclobutrazol } & $20 \mathrm{ppm}$ & 41.2 & 42.6 & 14.9 & 18.3 \\
\hline & $40 \mathrm{ppm}$ & 36.4 & 35.2 & 16.3 & 21.6 \\
\hline & $60 \mathrm{ppm}$ & 31.2 & 30.6 & 18.9 & 24.3 \\
\hline \multirow{3}{*}{ Cycocel } & $1000 \mathrm{ppm}$ & 43.2 & 45.4 & 14.5 & 17.9 \\
\hline & $2000 \mathrm{ppm}$ & 38.9 & 38.9 & 16.1 & 20.4 \\
\hline & $3000 \mathrm{ppm}$ & 34.2 & 32.7 & 17.6 & 22.6 \\
\hline L.S.D. at $5 \%$ & & 4.37 & 6.28 & 1.21 & 2.43 \\
\hline
\end{tabular}

\section{Leaves fresh and dry weights (g):}

Data illustrated in Table (3) state that all studied treatments of paclobutrazol and cycocel statistically increased the fresh and dry weights of leaves per plant over control in both seasons. Specifically, 3000 ppm cycocel-sprayed plants included the heaviest fresh and dry weights of leaves/plant, followed in descending order by the highest concentration of paclobutrazol in the two seasons. Besides, cycocel and paclobutrazol at the medium concentrations recorded high significant increments in this respect in both seasons of this study. On the reverse, the lowest values of leaves fresh and dry weights were recorded by the un-treated control plants in the two seasons. Such results obtained here show a similar trend to those obtained by many investigators worked on 
paclobutrazol and cycocel on other plants. In this concern, examples include Saker (2004) on Hibiscus rosa sinensis and Tabernaemontana coronaria, Youssef (2004) on Strelitzia reginae, Abd El-Kader (2009) on Cestrum elegans and Tecoma stans, Sibel et al. (2009) on Consolida orientalis, Gosh et al. (2010) on Jatropha curcas, Ribeiro et al. (2011) on sunflower, Jungklang and Saengnil (2012) on patumma cv. Chiang Mai Pink, Youssef, and Abd El-Aal (2013) on Tabernaemontana coronaria, Eissa (2014) on Murraya exotica and Duranta repens plants, Turky (2015) on Hibiscus plant and Mohamed (2016) on kumquat plants.

Table 3. Effect of paclobutrazol and cycocel on fresh and dry weights of leaves/plant of Chrysanthemum frutescens during 2013 and 2014 seasons.

\begin{tabular}{|c|c|c|c|c|c|}
\hline \multirow[b]{2}{*}{ Treatments } & \multirow[t]{2}{*}{ Parameters } & \multicolumn{2}{|c|}{ Leaves fresh weight $(\mathrm{g})$} & \multicolumn{2}{|c|}{ Leaves dry weight $(\mathrm{g})$} \\
\hline & & $1^{\text {st }}$ Season & $2^{\text {nd }}$ Season & $1^{\text {st }}$ Season & $2^{\text {nd }}$ Season \\
\hline Control & & 92.3 & 108.3 & 11.04 & 12.96 \\
\hline \multirow{3}{*}{ Paclobutrazol } & $20 \mathrm{ppm}$ & 102.3 & 119.6 & 12.24 & 14.28 \\
\hline & $40 \mathrm{ppm}$ & 109.6 & 131.4 & 13.08 & 15.72 \\
\hline & $60 \mathrm{ppm}$ & 121.4 & 139.2 & 14.52 & 16.68 \\
\hline \multirow{3}{*}{ Cycocel } & $1000 \mathrm{ppm}$ & 104.0 & 123.4 & 12.18 & 14.76 \\
\hline & $2000 \mathrm{ppm}$ & 112.6 & 134.7 & 13.44 & 16.08 \\
\hline & $3000 \mathrm{ppm}$ & 125.4 & 146.2 & 15.41 & 17.11 \\
\hline L.S.D. at $5 \%$ & & 7.39 & 8.30 & 0.98 & 1.36 \\
\hline
\end{tabular}

\section{B. Flowring growth parameters:}

1. Time to flowering (days):

Result data of time to the first flower showing colour (as an indicator of flower development by days determined from the beginning of the planting March, $1^{\text {st }}$ in the two seasons) are shown in Table (4).

All paclobutrazol and cycocel treatments delayed the flowering (increasing the number of days from planting to start flowering) of Chrysanthemum frutescence plants as compared with untreated control plants in both seasons. To elaborate in detail, the greatest delay of Chrysanthemum frutescence flowering was gained by $60 \mathrm{ppm}$ paclobutrazolsprayed plants as it recorded 178.0 and 181.7 days, followed in descending order by using the high concentration of cycocel as it scored 174.3 and 177.2 days, in the first and second seasons, respectively. Moreover, paclobutrazol at $40 \mathrm{ppm}$ and cycocel at $2000 \mathrm{ppm}$ gave more delaying in flowering start in both seasons. On the reverse, the earliest flowering was occurred by untreated plants as it registered 159.6 and 152.3 days, followed in ascending order by
2000 ppm cycocel-sprayed plants which gave 161.3 and 159.0 days, in the first and second seasons, respectively.

\section{Flowers number / plant:}

Data outlined in Table (4) designate that all tested paclobutrazol and cycocel treatments increased the flowers number / plant when compared with untreated control plants in both seasons. As a matter of fact, the increase in flowers number / plant of Chrysanthemum frutescence plants was proportionally with the increment of paclobutrazol or cycocel concentration, hence the highest number of flowers/plant was recorded by 60 ppm paclobutrazolsprayed plant as it scored 41.7 and 49.6 flowers/plant, followed in descending order by 3000 ppm cycocel-sprayed plants which recorded 39.2 and 46.4 flowers/plant in the first and second seasons, respectively. Also, paclobutrazol at $40 \mathrm{ppm}$ and cycocel at $2000 \mathrm{ppm}$ gave high increments in this parameter in both seasons.

Table 4. Effect of paclobutrazol and cycocel on time to flowering and flowers number/plant of Chrysanthemum frutescens during 2013 and 2014 seasons.

\begin{tabular}{|c|c|c|c|c|c|}
\hline \multirow[b]{2}{*}{ Treatments } & \multirow[t]{2}{*}{ Parameters } & \multicolumn{2}{|c|}{ Time to flowering (days) } & \multicolumn{2}{|c|}{ Flowers number/plant } \\
\hline & & $1^{\text {st }}$ Season & $2^{\text {nd }}$ Season & $1^{\text {st }}$ Season & $2^{\text {nd }}$ Season \\
\hline Control & & 159.6 & 152.3 & 23.1 & 28.9 \\
\hline \multirow{3}{*}{ Paclobutrazol } & $20 \mathrm{ppm}$ & 164.2 & 161.4 & 29.6 & 36.0 \\
\hline & $40 \mathrm{ppm}$ & 169.7 & 172.3 & 36.2 & 42.4 \\
\hline & $60 \mathrm{ppm}$ & 178.0 & 181.7 & 41.7 & 49.6 \\
\hline \multirow{3}{*}{ Cycocel } & $1000 \mathrm{ppm}$ & 161.3 & 159.0 & 26.7 & 34.2 \\
\hline & $2000 \mathrm{ppm}$ & 167.8 & 168.6 & 34.2 & 40.5 \\
\hline & $3000 \mathrm{ppm}$ & 174.3 & 177.2 & 39.2 & 46.4 \\
\hline L.S.D. at $5 \%$ & & 7.22 & 8.14 & 4.11 & 5.39 \\
\hline
\end{tabular}




\section{Fresh and dry weights of flowers (g):}

Data outlined in Table (5) report that all utilized treatments of paclobutrazol and cycocel statistically increased the fresh and dry weights of flowers per plant over the control in both seasons. The heaviest flowers fresh and dry /plant were gained by 3000 ppm cycocel-sprayed plants, followed in descending order using paclobutrazol at the high concentration $(60 \mathrm{ppm})$ in the two seasons. Moreover, cycocel at $2000 \mathrm{ppm}$ and paclobutrazol at $40 \mathrm{ppm}$ gave highly significant increases in flowers fresh and dry weights/plant in the two seasons. In contrast, the lowest values of flowers fresh and dry weights/plant were obtained in un-treated control plants in the two seasons.

\section{Show value (plant width / height ratio):}

Data presented in Table (5) show that all tested treatments of paclobutrazol and cycocel increased the show value of Chrysanthemum frutescens plants when compared with the control plants in both seasons. The highest record of show value was scored by $60 \mathrm{ppm}$ paclobutrazol-sprayed plants as it registered 0.97 and 0.95 , followed in descending order by $3000 \mathrm{ppm}$ cycocel-sprayed plants as it recorded 0.92 and 0.88 in the first and second seasons, respectively. Moreover, both paclobutrazol at $40 \mathrm{ppm}$ and cycocel at $2000 \mathrm{ppm}$ gave highly records in this concern in both seasons. On the contrary, the lowest values were scored by control plants which scored 0.45 and 0.43 followed in ascending order by paclobutrazol and cycocel at the lowest concentration, in the two seasons.

The results of flowering growth traits as affected by paclobutrazol and cycocel coincide with those of Sibel et al. (2009) on Consolida orientalis L,Wilkinson and Richards (1988) on Camellia $\mathrm{x}$ Williamsii, Wang and Gregg (1991) on hibiscus, De Baerdemaeker et al. (1994) on Gardenia jasminoides Ellis cultivar 'Wetchii', Karaguzel and Ortacesme (2002) on Bougainvillea glabra 'Sanderiana', Karaguzel et al. (2004) on Lupinus varius, Saker (2004) on Hibiscus rosa sinensis and Tabernaemontana coronaria, Youssef (2004) on Strelitzia reginae, Abd El-Kader (2009) on Cestrum elegans and Tecoma stans, Mansuroglu et al. (2009) on Consolida orientalis and Jungklang, Youssef and Abd El-Aal (2013) on Tabernaemontana coronaria and Eissa (2014) on Murraya exotica and Duranta repens plants.

Table 5. Effect of paclobutrazol and cycocel on fresh, dry weights of flowers/plant and show value of Chrysanthemum frutescens during 2013 and 2014 seasons.

\begin{tabular}{ccccccccc}
\hline \multirow{2}{*}{ Treatments } & \multirow{2}{*}{ Parameters } & \multicolumn{2}{c}{ Flowers fresh weight $(\mathrm{g})$} & \multicolumn{2}{c}{ Flowers dry weight $(\mathrm{g})$} & \multicolumn{2}{c}{ Show value } \\
\cline { 3 - 8 } Control & & 184 & 224 & 22.1 & 29.17 & 0.45 & 0.43 \\
\hline \multirow{3}{*}{ Paclobutrazol } & & $20 \mathrm{ppm}$ & 232 & 288 & 27.84 & 37.41 & 0.59 & 0.55 \\
& $40 \mathrm{ppm}$ & 288 & 336 & 34.56 & 43.68 & 0.72 & 0.77 \\
& $60 \mathrm{ppm}$ & 328 & 392 & 39.36 & 51.01 & 0.97 & 0.95 \\
\hline \multirow{3}{*}{ Cycocel } & $1000 \mathrm{ppm}$ & 234 & 308 & 28.11 & 40.12 & 0.52 & 0.51 \\
& $2000 \mathrm{ppm}$ & 306 & 360 & 36.72 & 46.92 & 0.68 & 0.63 \\
& $3000 \mathrm{ppm}$ & 351 & 414 & 42.23 & 55.89 & 0.92 & 0.88 \\
\hline L.S.D. at 5\% & & 12.37 & 18.26 & 3.19 & 4.36 & 0.11 & 0.12 \\
\hline
\end{tabular}

\section{Root growth parameters}

\section{Roots number / plant}

The data obtained on the number of roots per plant at the end of the first and second seasons (December $1^{\text {st }}$ ) as affected by paclobutrazol and cycocel are presented in Table (6).

Result data showed that the mean number of roots per plant increased progressively with the increasing of cycocel or paclobutrazol concentrations in both seasons. So, the highest concentrations of cycocel showed to be the most effective one for inducing the highest number of roots per plant as it scored 21.3 and 20.1 roots / plant, followed in descending order by the high rate of paclobutrazol as it recorded 19.7 and 18.3 roots / plant in the first and second seasons, respectively. In addition, the medium rate of cycocel and paclobutrazol recorded highly significant increments in this respect in both seasons. Irrespective of the control plants, the lowest values of this parameter were gained by using the low rate of cycocel and paclobutrazol in both seasons.

\section{Fresh and dry weights of roots $(\mathrm{g})$ :}

Data in Table (6) denoted that all applied treatments of paclobutrazol and cycocel statistically increased the fresh and dry weights of roots per plant as compared with the control in both seasons. To elaborate, the highest concentration of cycocel showed its superiorities in this concern, as it induced the heaviest fresh and dry weights of roots/plant, followed in descending order by the highest concentration of paclobutrazol in the two seasons. In addition, cycocel and paclobutrazol at the medium concentration recorded high significant increases in this regard in both seasons of this study. On the opposite side, the lowest values of roots fresh and dry weights were scored by un-treeated plants in the two seasons. Results here are in agreement with those obtained by Youssef (2004) on Strelitzia reginae, Adham (2001) on Althaea rosea, Saker (2004) on Tabernaemontana coronaria and Hibiscus rosea sinensis plants, El-Malt et al. (2006) on Hippeastrum vittatum, Pinto et al. (2006) on potted 
Thai Tulip, Abd El-Kader (2009) on Tecoma stans and Cestrum elegans, Ribeiro et al. (2011) on sunflower. Youssef and Abd El-Aal (2013) on Tabernaemontana coronaria, Eissa (2014) on
Duranta repens and Murraya exotica plants, Turky (2015) on Hibiscus rosea sinensis plant and Mohamed (2016) on kumquat plant.

Table 6. Effect of paclobutrazol and cycocel on number, fresh and dry weights of roots/plant of Chrysanthemum frutescens during 2013 and 2014 seasons.

\begin{tabular}{|c|c|c|c|c|c|c|c|}
\hline \multicolumn{2}{|c|}{ Parameters } & \multicolumn{2}{|c|}{ Roots number/plant } & \multicolumn{2}{|c|}{ Roots fresh weight(g) } & \multicolumn{2}{|c|}{ Roots dry weight(g) } \\
\hline Treatments & & $1^{\text {st }}$ Season & $2^{\text {nd }}$ Season & $1^{\text {st }}$ Season & $2^{\text {nd }}$ Season & $1^{\text {st }}$ Season & $2^{\text {nd }}$ Season \\
\hline Control & & 12.6 & 11.4 & 15.6 & 16.1 & 1.72 & 2.19 \\
\hline \multirow{3}{*}{ Paclobutrazol } & $20 \mathrm{ppm}$ & 14.9 & 13.9 & 19.41 & 19.6 & 2.14 & 2.35 \\
\hline & $40 \mathrm{ppm}$ & 17.2 & 16.2 & 22.1 & 22.7 & 2.42 & 2.77 \\
\hline & $60 \mathrm{ppm}$ & 19.7 & 18.3 & 25.4 & 25.6 & 2.79 & 3.15 \\
\hline \multirow{3}{*}{ Cycocel } & $1000 \mathrm{ppm}$ & 16.1 & 14.9 & 22.4 & 22.5 & 2.64 & 2.81 \\
\hline & $2000 \mathrm{ppm}$ & 18.7 & 17.6 & 26.8 & 26.4 & 3.10 & 3.30 \\
\hline & $3000 \mathrm{ppm}$ & 21.3 & 20.1 & 29.4 & 30.1 & 3.38 & 3.76 \\
\hline L.S.D. at $5 \%$ & & 1.39 & 1.71 & 2.21 & 1.34 & 0.24 & 0.26 \\
\hline
\end{tabular}

\section{Chemical composition determination:}

Results of chemical composition of Chrysanthemum frutescens leaf samples (Tables, 7,8 and 9) revealed that paclobutrazol and cycocel treatments resulted in increments in NPK, total carbohydrates \%, total chlorophylls (mg /100 g F.W) and total phenols (mg /100 g F.W) when compared with the controls in both seasons. To add detail, the highest values of $\mathrm{N}$ and $\mathrm{K}$ contents of Chrysanthemum frutescens leaf were registered by $60 \mathrm{ppm}$ paclobutrazol-sprayed plants, followed in descending order by 3000ppm cycocel-sprayed plants in the two seasons. Meanwhile, the highest leaf phosphorus content was gained by $3000 \mathrm{ppm}$ cycocel-sprayed plants, followed by $60 \mathrm{ppm}$ paclobutrazol-sprayed plants in the two seasons. On the contrast, all studied treatments of paclobutrazol and cycocel decreased leaf total indoles content $(\mathrm{mg}$ /100 g F.W), especially 60 ppm paclobutrazolsprayed plants as compared with the controls in both seasons.

Table7. Effect of paclobutrazol and cycocel on leaf N, P and K contents in leaves of Chrysanthemum frutescens during 2013 and 2014 seasons.

\begin{tabular}{|c|c|c|c|c|c|c|c|}
\hline \multirow[b]{2}{*}{ Treatments } & \multirow[t]{2}{*}{ Parameters } & \multicolumn{2}{|c|}{$\mathrm{N} \%$} & \multicolumn{2}{|c|}{$\mathrm{P} \%$} & \multicolumn{2}{|c|}{$\mathrm{K} \%$} \\
\hline & & $1^{\text {st }}$ Season & $2^{\text {nd }}$ Season & $1^{\text {st }}$ Season & $2^{\text {nd }}$ Season & $1^{\text {st }}$ Season & $2^{\text {nd }}$ Season \\
\hline Control & & 2.19 & 2.02 & 0.224 & 0.221 & 1.27 & 1.32 \\
\hline \multirow{3}{*}{ Paclobutrazol } & $20 \mathrm{ppm}$ & 2.24 & 2.11 & 0.229 & 0.226 & 1.34 & 1.49 \\
\hline & $40 \mathrm{ppm}$ & 2.36 & 2.29 & 0.234 & 0.231 & 1.46 & 1.62 \\
\hline & $60 \mathrm{ppm}$ & 2.39 & 2.34 & 0.239 & 0.236 & 1.69 & 1.78 \\
\hline \multirow{3}{*}{ Cycocel } & $1000 \mathrm{ppm}$ & 2.24 & 2.14 & 0.231 & 0.229 & 1.32 & 1.46 \\
\hline & $2000 \mathrm{ppm}$ & 2.31 & 2.26 & 0.237 & 0.234 & 1.41 & 1.58 \\
\hline & $3000 \mathrm{ppm}$ & 2.37 & 2.31 & 0.241 & 0.239 & 1.58 & 1.67 \\
\hline L.S.D. at $5 \%$ & & 0.14 & 0.16 & 0.014 & 0.012 & 0.13 & 0.14 \\
\hline
\end{tabular}

Table 8. Effect of Paclobutrazol and Cycocel on total carbohydrates (\%) and total chlorophyllus (mg/100g FW) in leaves of Chrysanthemum frutescens during 2013 and 2014 seasons.

\begin{tabular}{|c|c|c|c|c|c|}
\hline \multirow[b]{2}{*}{ Treatments } & \multirow[t]{2}{*}{ Parameters } & \multicolumn{2}{|c|}{ Total carbohydrates (\%) } & \multicolumn{2}{|c|}{ Total chlorophylls(mg/100g F.W) } \\
\hline & & $1^{\text {st }}$ Season & $2^{\text {nd }}$ Season & $1^{\text {st }}$ Season & $2^{\text {nd }}$ Season \\
\hline Control & & 8.14 & 9.26 & 142.6 & 154.2 \\
\hline \multirow{3}{*}{ Paclobutrazol } & $20 \mathrm{ppm}$ & 10.31 & 11.84 & 154.7 & 169.3 \\
\hline & $40 \mathrm{ppm}$ & 12.14 & 13.01 & 169.4 & 181.3 \\
\hline & $60 \mathrm{ppm}$ & 13.02 & 13.48 & 174.2 & 187.2 \\
\hline \multirow{3}{*}{ Cycocel } & $1000 \mathrm{ppm}$ & 9.82 & 11.24 & 149.4 & 171.3 \\
\hline & $2000 \mathrm{ppm}$ & 11.8 & 12.89 & 164.3 & 179.4 \\
\hline & $3000 \mathrm{ppm}$ & 12.62 & 13.24 & 171.3 & 184.6 \\
\hline L.S.D. at $5 \%$ & & 1.40 & 1.27 & 12.11 & 11.36 \\
\hline
\end{tabular}


Table 9. Effect of paclobutrazol and cycocel on total indoles and total phenols (mg/100g FW) in leaves of Chrysanthemum frutescens during 2013 and 2014 seasons.

\begin{tabular}{llcccc}
\hline \multirow{2}{*}{ Treatments } & \multirow{2}{*}{ Parameters } & \multicolumn{2}{c}{ Total indols $(\mathrm{mg} / 100 \mathrm{~g}$ F.W $)$} & \multicolumn{2}{c}{ Total phenols $(\mathrm{mg} / 100 \mathrm{~g}$ F.W) } \\
\cline { 3 - 6 } Control & & $1^{\text {st }}$ Season & $2^{\text {nd }}$ Season & $1^{\text {st }}$ Season & $2^{\text {nd }}$ Season \\
\hline \multirow{3}{*}{ Paclobutrazol } & $20 \mathrm{ppm}$ & 264.2 & 279.3 & 123.4 & 117.3 \\
& $40 \mathrm{ppm}$ & 257.4 & 264.1 & 136.0 & 128.4 \\
& $60 \mathrm{ppm}$ & 243.2 & 251.6 & 148.2 & 137.4 \\
Cycocel & $1000 \mathrm{ppm}$ & 231.6 & 238.4 & 153.7 & 149.2 \\
& $2000 \mathrm{ppm}$ & 259.4 & 268.0 & 132.0 & 126.8 \\
& $3000 \mathrm{ppm}$ & 248.7 & 257.4 & 145.6 & 135.0 \\
\hline L.S.D. at 5\% & & 238.2 & 243.0 & 151.2 & 146.6 \\
\hline
\end{tabular}

The results obtained here go in line with that obtained by Selim (1985) on Bougainvillea Mrs Butte, Selim (1990) on Pelargonium zonale, Youssef (2004) on Strelitzia reginae, Saker (2004) on Hibiscus rosa sinensis and Tabernaemontana coronaria shrubs, El-Malt et al. (2006) on Hippeastrum vittatum, Abd El-Kader (2009) on Cestrum elegans and Tecoma stans, Jungklang and Saengnil (2012) on patumma cv. Chiang Mai Pink, Youssef and Abd El-Aal (2013) on Tabernaemontana coronaria, Eissa (2014) on Murraya exotica and Duranta repens plants, Turky (2015) on Hibiscus rosea sinensis plant and Mohamed (2016) on kumquat plant.

As for the explanation of the incremental effect of paclobutrazol and cycocel on chemical constituents in leaf of Chrysanthemum frutescence, it could be interpreted here on the basis that paclobutrazol and cycocel treatments stimulated the endogenous cytokinins synthesis and there is an intimate relationship between cytokinins and chlorophylls metabolism in both excided or detached leaf disks and intact plants i.e., cytokinins retard chlorophylls degradation, preserve it and increase its synthesis (Devlin and Witham, 1983). Besides, cytokinins activate a number of enzymes participating in a wide range of metabolic reactions in the leaves. These reactions included the maturation of proplastid into chloroplasts. These enzymes could be divided into two groups according to their response to cytokinins. The first group of enzymes could be said to relate to chloroplast differentiation, while the second group could be related to cytokinin stimulated group (Kulaeva, 1979). Also, the increase in chlorophyll content due to growth retardants treatments might be attributed to the character of some growth retardants on depressing leaf area which lead to intensification of pigments in leaf.

Conclusively, results obtained in this research study made it possible to achieve more dwarfed plants of Chrysanthemum frutescence with many formed flowers (Tables, 2-5). Treatments of paclobutrazol at $60 \mathrm{ppm}$ or cycocel at $3000 \mathrm{ppm}$ gave a good display (show value) of a flowering pot of Chrysanthemum frutescens plant with optimum vegetative and flowering characteristics from the commercial point of view when compared with the other remaining treatments or control.

\section{References}

A.O.A.C., 1990. Official Methods of Analysis of Association of Official Analytical Chemists. Pub. A.O.A.C. INC. Suite 400, 22201 USA Fifteenth Ed. pp: 62-63, 236 and 877-878.

Abd El-Kader, S.F.A., 2009. Physiological studies on growth and flowering of some shrubs. Ph.D. Thesis, Fac. Agric. Moshtohor, Benha Univ.,PP:114.

Adham, H.E.I., 2001. Effect of some growth retardants, pinching and planting date on growth, flowering and chemical composition of Althaea rosea, L. Ph.D. Thesis, Fac. Agric., Cairo Univ.

Armitage, A. M., 2004. Armitage's garden annuals: A color encyclopedia, 1St Edition, Timber Press, Inc. Portland - Cambridge, PP:368.

Beattie, D.J., E.J. Holcomb and C.F. Deneke, 1990. Effects of uniconazole and paclobutrazol on plant height and flowering in Physostegia virginiana and Cheloneoblique. Plant Growth Regulator Society of America, 18(4): 187-193.

Berghage, R.D., R.D. Heins, M. Karlsson, J. Erwin and W. Carlson, 1989. Pinching technique influences lateral shoot development in poinsettia. J. Amer. Soc. Hort. Sci., 114(6): 909914.

Black, C.D., D.O. Evans, L.E. Ensminger, J.L. White, F.E. Clark and R.C. Dinauer, 1982. Methods of soil analysis. Part 2. Chemical and microbiological properties. 2nd Ed. Soil., Soc. of Am. Inc. Publ., Madison, Wisconsin, U.S.A.PP: 1143 .

Brown, J.D. and O. Lilleland, 1946. Rapid determination of potassium and sodium in plant material and soil extract by flame photometry. Proc. Amer. Soc., Hort., Sci., 48: 341-346.

Chany, W.R., 2005. Growth retardants: A promising tool for managing urban trees. Env. Toxicol. Chem., 29: 1224-1236.

Davis, T.D. and A.S. Andersen, 1989. Growth retardants as aids in adapting new floricultural crops to pot culture. Acta Horticulturae, 252: 77- 
85.

De Baerdemaeker, C.I., J.M. Huylenbroeck and P.C. Debergh, 1994. Influence of paclobutrazol and photoperiod on growth and flowering of Gardenia jasminoides Ellis cultivar 'Wetchii'. Scientia Horticulturae, 58: 315-324.

Devlin, M. and H. Witham, 1983. Plant Physiology, 4th Ed. Publishers Willard, Grant Press, Boston.PP:577.

Eissa, E.A.T. 2014. Production of Murraya exotica and Duranta repens as pot plants by CCC and PP333. M. Sc. Thesis, Fac. of Agric., Kafr ElShikh Univ.

El-Malt, A.A.T., E.E. El-Maadawy, M.A. El-Khateeb and Z.H. El-Sadak, 2006. Physiological studies on Hippeastrum vittatum L. plants.2- Effect of NPK, CCC and BA on growth, bulblet production and flowering. Egypt.J. of Appl. Sci., (6B): 724742 .

Fletcher, R.A., A. Gill, T.D. Davis and N. Sankhla, 2000. Triazoles as plant growth regulators and stress protectants. Horticulture Review, 24: 55138.

Gosh, A., J. Chikara, D.R. Chandhari, A.R. Prakashi, G. Boricha and A. Zala, 2010. Paclobutrazol arrests vegetative growth and unveils unexpressed yield potential of Jathropha curcas. Journal of Plant Growth Regulation, 29: 307-315.

Herbert, D., P.J. Phipps and R.E. Strange, 1971. Determination of total carbohydrates, Methods in Microbiology, 5(8): 290-344.

Hucker, T. and G. Catroux, 1980. Phosphorus in sewage ridge and animals wastes slurries. Proceeding of the EEC Seminar, Haren (Gr): Gromingen Netherlands 12, 13 June.

Jungklang, J. and K. Saengnil, 2012. Effect of paclobutrazol on patumma cv. Chiang Mai Pink under water stress. Songklanakarin J. Sci. Technol., 34(4): 361-366.

Karaguzel, O., I. Baktir, S. Cakmakci and V. Ortacesme, 2004. Growth and flowering responses of Lupinus varius L. to paclobutrazol. HortScience, 39(7): 1659-1663.

Karaguzel, O. and V. Ortacesme, 2002. Influence of paclobutrazol on the growth and flowering of Bougainvillea glabra 'Sanderiana'. Ziraat Fakultesi Dergisi, Akdeniz Universitesi, 15(1): 79-84.

Kulaeva, O.N., 1979. Cytokinin action on enzyme activities in plants. In plant growth substances. (Ed.) F. Skoog, Springer-verlage Berlin, Heidelberg. New York (1980), pp: 119-128.

Mansuroglu, S., O. Karaguzel, V. Ortacesme and M.S. Sayan, 2009. Effect of paclobutrazol on flowering, leaf and flower colour of Consolida orientalis. Pakistan Journal of Botany, 41(5): 2323-2332.

.Mohamed, A.A.A. 2016. Physiological studies on some fruity trees which used in softscape. M. Sc. Hort. Dept. Fac. Of Agric., Benha Univ.,PP.106.
PGRSA, 2007. Plant growth regulation handbook of the Plant Growth Regulation Society of America. 4th Edition. The Plant Growth Regulation Society of America, Athens.

Pinto, A.C.R., T.T. Graziano, J.C. Barbosa and F.B. Lasmar, 2006. Growth retardants on production of flowering potted Thai tulip. Bragantia, 65: 369-380.

Rademacher, W. 2000. Growth Retardants: Effects on gibberellin biosynthesis and other metabolic pathways. Annual Review of Plant Physiology and Plant Molecular Biology, 51: 501-531.

Ribeiro, D.M., M. Caroline, B. Jackson, B.R. Glayton and R.S. Barros, 2011. Effects of autoclaving on the physiological action of Paclobutrazol. Agricultural Sciences, 2(3): 191197.

Saker, A.M.I., 2004. Physiological studies on growth and flowering of some ornamental shrubs. M.Sc. Thesis Fac. Agric. Moshtohor, Zagazig Univ.

Selim, S.M., 1985. Effect of some growth regulators on growth, flowering production of Bougainvillea plants. Ph.D. Thesis, Fac. Agric., Cairo Univ.

Selim, S.M., 1990. Effect of urea fertilization and cycocel sprays on Pelargonium zonale Ait. IIEffect on chemical composition. J. Agric. Res. Tanta Univ., 16(4): 757-766.

Sibel, M., O. Karaguzel, V. Ortacesme and M.S. Sayan, 2009. Effect of paclobutrazol on flowering, leaf and flower colour of Consolida orientalis. Pak. J. Bot., 41(5): 2323-2332.

Snedecor, G.W. and W.G. Cochran, 1989. Statistical methods. 7th Ed. Iowa state Univ. Press. Ames Iowa, USA.

Taiz, L. and E. Zeiger, 2006. Plant Physiology. 4th edition. Sinauer Associates, Inc., Publishers,Sunderland.P.775.

Turky, B.K.A. 2015. Physiological studies on some ornamental shrubs which used in garden landscape. M. Sc. Hort. Dept. Fac. Of Agric., Benha Univ.,PP:120.

Wang, Y.T. and L.L. Gregg, 1991. Modification of hibiscus growth by treating unrooted cuttings and potted plants with uniconazole or paclobutrazol. Journal of Plant Growth Regulation, 10(1): 47-51.

Wilkinson, R.J. and D. Richards, 1988. Influence of paclobutrazol on the growth and flowering of Camellia x Williamsii. HortScience, 23(2): 359360.

Youssef, A.S.M., 2004. Physiological studies on growth and flowering of Strelitzia reginae Ait. Plant. Ph.D. Thesis, Fac. of Agric., Moshtohor, Zag. Univ.,PP:369.

Youssef, A.S.M. and M.M.M. Abd El-Aal, 2013. Effect of paclobutrazol and cycocel on growth, flowering, chemical composition and histological features of potted Tabernaemontana coronaria Stapf plant. Journal of Applied Sciences Research, 9(11): 5953-5963. 


\section{تاثير الرش بالباكلويترازول والسيكوسيل علي النمو والازهار والمحتوي الكيماوي لنباتات المندليه الناميه في الاصص}

$$
\text { قسم البساتين - كليه الزراعة - جامعه بنها- مصر عبد العاطي }
$$

اجريت تجربة اصص خلال موسمي 2014،2013 وذلك لدراسه تاثير الرش بالباكلوبترازول بتركيز 60،40،20، جزء في المليون

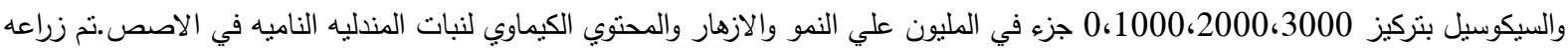

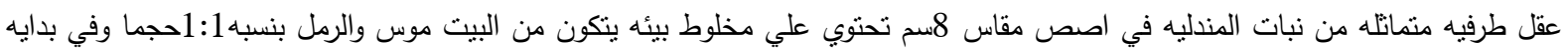

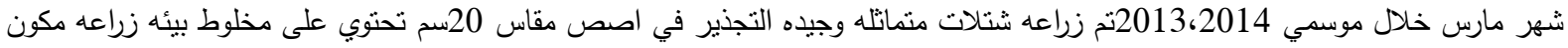

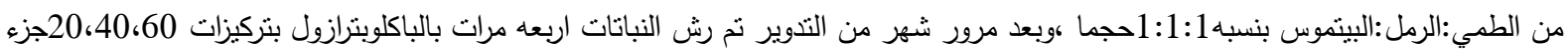
في المليون والسيكوسيل بتركيزات 3000،2000،1000جزء في المليون بالاضافه الي الرش بماء الصنبور كمعامله كنترول وكانت فتره الرش بين

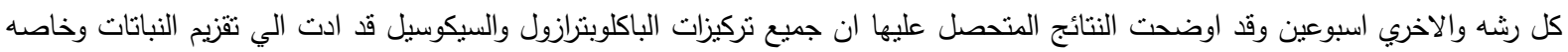

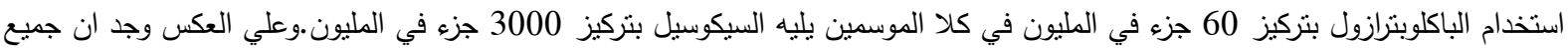

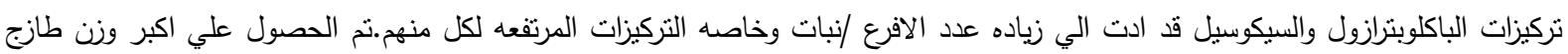

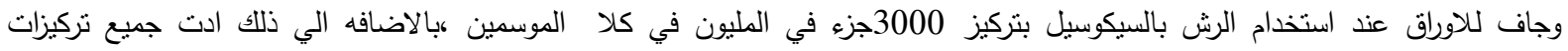
الباكلوبترازول والسيكوسيل الي تاخير الازهار وذلك عند المقارنه بالكنترول الذي اعطي اسرع ازهار في كلا الموسمين واعطي الرش بالبالباكلوبترازول

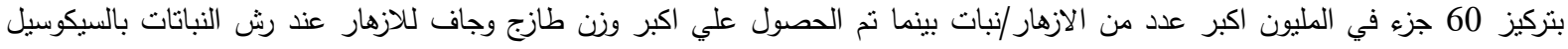
بتركيز 3000جزء في المليون في كلا الموسمين.تم الحصول علي اعلي قيمه جماليه عند استخدام التركيز العالي لكل من الباكلوبترازول

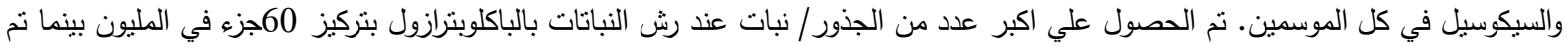
الحصول علي اكبر وزن طازج وجاف للجذور عند رش النباتات بالسيكوسيل بتركيز 3000جزء في المليون.اعطت جميع معاملاتلات الباكلوبترازول

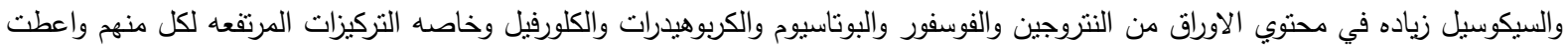

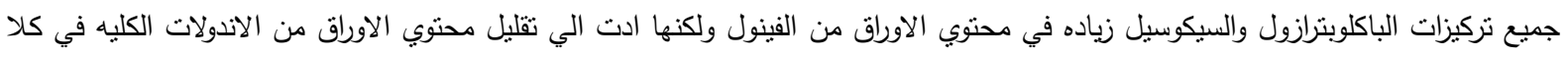
الموسمين. 